\title{
Archaeological Monitoring of the Ashby Street Drainage Project, San Antonio, Bexar County, Texas
}

Anne A. Fox

I. Waynne Cox

Follow this and additional works at: https://scholarworks.sfasu.edu/ita

Part of the American Material Culture Commons, Archaeological Anthropology Commons, Environmental Studies Commons, Other American Studies Commons, Other Arts and Humanities Commons, Other History of Art, Architecture, and Archaeology Commons, and the United States History Commons

Tell us how this article helped you.

This Article is brought to you for free and open access by the Center for Regional Heritage Research at SFA ScholarWorks. It has been accepted for inclusion in Index of Texas Archaeology: Open Access Gray Literature from the Lone Star State by an authorized editor of SFA ScholarWorks. For more information, please contact cdsscholarworks@sfasu.edu. 


\section{Archaeological Monitoring of the Ashby Street Drainage Project, San Antonio, Bexar County, Texas}

\section{Creative Commons License}

\section{(c) (1) \&}

This work is licensed under a Creative Commons Attribution-NonCommercial 4.0 International License 


\section{ARCHAEOLOGICAL MONITORING OF THE ASHBY STREET DRAINAGE PROJECT, SAN ANTONIO, BEXAR COUNTY, TEXAS}

Anne A. Fox and I. Waynne Cox

Center for Archaeological Research The University of Texas at San Antonio Archaeological Survey Report, No. 176 



\section{ARCHAEOLOGICAL MONITORING OF THE ASHBY STREET DRAINAGE PROJECT, SAN ANTONIO, BEXAR COUNTY, TEXAS}

Anne A. Fox and I. Waynne Cox

Center for Archaeological Research

The University of Texas at San Antonio ${ }^{\circledR}$ Archaeological Survey Report, No. 176 


\begin{abstract}
In April 1987, the authors monitored excavation of trenches for a drainage project in the area of North St. Mary's and Ashby Streets north of downtown San Antonio. The main concern was to observe and record the location and configuration of the Upper Labor Acequia in this area when it was crossed by trenching machines. A cross section of the acequia was recorded at the intersection of St. Mary's and Myrtle Streets.
\end{abstract}




\section{ACKNOWLEDGMENTS}

We would like to acknowledge the assistance of Norma Rodriguez, secretary of the City of San Antonio, for help in our search for information in the records of the city council. We also thank John Leal, Bexar County archivist, for his contributions on the history of the construction of the Upper Labor Acequia. 


\section{INTRODUCTION}

In April 1987, the Center for Archaeological Research at The University of Texas at San Antonio entered into a contract with the City of San Antonio to monitor construction of a drainage project. The project involved the excavation of trenches, laying of pipe, immediate refilling of the trenches, and repaving in the area of North St. Mary's and Ashby Streets just north of downtown San Antonio (Fig. 1).

The area of concern within the drainage project was the section of St. Mary's Street between Ashby and Park Streets where the Upper Labor Acequia once ran parallel to the line of the present street and probably somewhere beneath it. The purpose of the archaeological monitoring was to find and record a cross section of the acequia when it was cut by the trenching machine, and to record its location in respect to the present street boundaries.

Monitoring was carried out by Anne Fox and I. Waynne Cox, under the general supervision of Thomas R. Hester, principal investigator. No artifacts were recovered during the project. All maps and field notes related to the project are on file at the Center for Archaeological Research.

\section{PREVIOUS WORK}

Excavations at various locations on other Spanish acequias in San Antonio (Schuetz 1970; Sorrow 1972; Fox 1978; Frkuska 1981; Fox 1985; Cox 1985, 1986) have yielded important information on their construction and subsequent abandonment. It has been found that they were originally open, unlined ditches and that it was not until ca. 1850 (Cox 1985:2) that sections of the acequias that ran through the main part of the city began to be lined with stone. The unlined acequias, for the most part, show up in cross section as relatively shallow depressions, filled either with soil from the surrounding area or with trash from neighboring households.

\section{HISTORICAL BACKGROUND}

The area impacted by this project was undeveloped land to the north of the Presidio and Villa of San Antonio de Bexar until the 1770s when it became what is known as the "Labor de Arriba," or Upper Labor (fields) created by the construction of the Upper Labor Acequia (Fig. 2). It was also known as the "Labor de Nuestra Señora de los Dolores" (Buck 1980:249).

The Upper Labor Acequia, rising from the headwaters of the San Antonio River and following the natural contours of the land to terminate at San Pedro Creek, was the last of the major irrigation systems created by the Spanish government. Its construction was initiated by a request of the citizens of San Antonio de Bexar to the governor of the Province of Texas, Barón Juan María de Ripperdá, who, after due consideration, had his consent published "at the beating of the drum at the door of the Court House, as is customary," on January 10, 1776 (Corner 1890:48). The governor ordered the interested parties to elect an acequiero, canal constructor or superintendent, to take charge of the project, and Toribio Fuentes was selected. The governor's orders also specified that the "water gates must be stone and mortar foundations," thus implying that the canal itself was an unlined ditch. On July 13, 1776, Fuentes asked to be relieved of the position and was replaced by Angel Galín (Corner 1890:48; Buck 1980:247-248).

By April 28, 1777, the work had advanced "as far as Lomita de Vieja," sufficient to allow the distribution of the first 26 suertes of land, some 25,233 varas of land (Corner 1890:49). These divisions were so designated because the size awarded for the uneven parcels depended upon one's "luck" in the drawing of the titles. The "Lomita de Vieja" was almost certainly Tobin Hill, the only perceptible rise along the route. Since the issuance of suertes implies the upper portion of the acequia was functioning at that time, it follows that some means of returning the flow to the river also existed. The most logical route was the lower channel, branching near Evergreen Avenue and Evergreen Court, that would later form the millrace for the Molino Blanco, a grist mill, near St. Mary's Street and Brooklyn Avenue. This also implies that this portion of the ditch is 


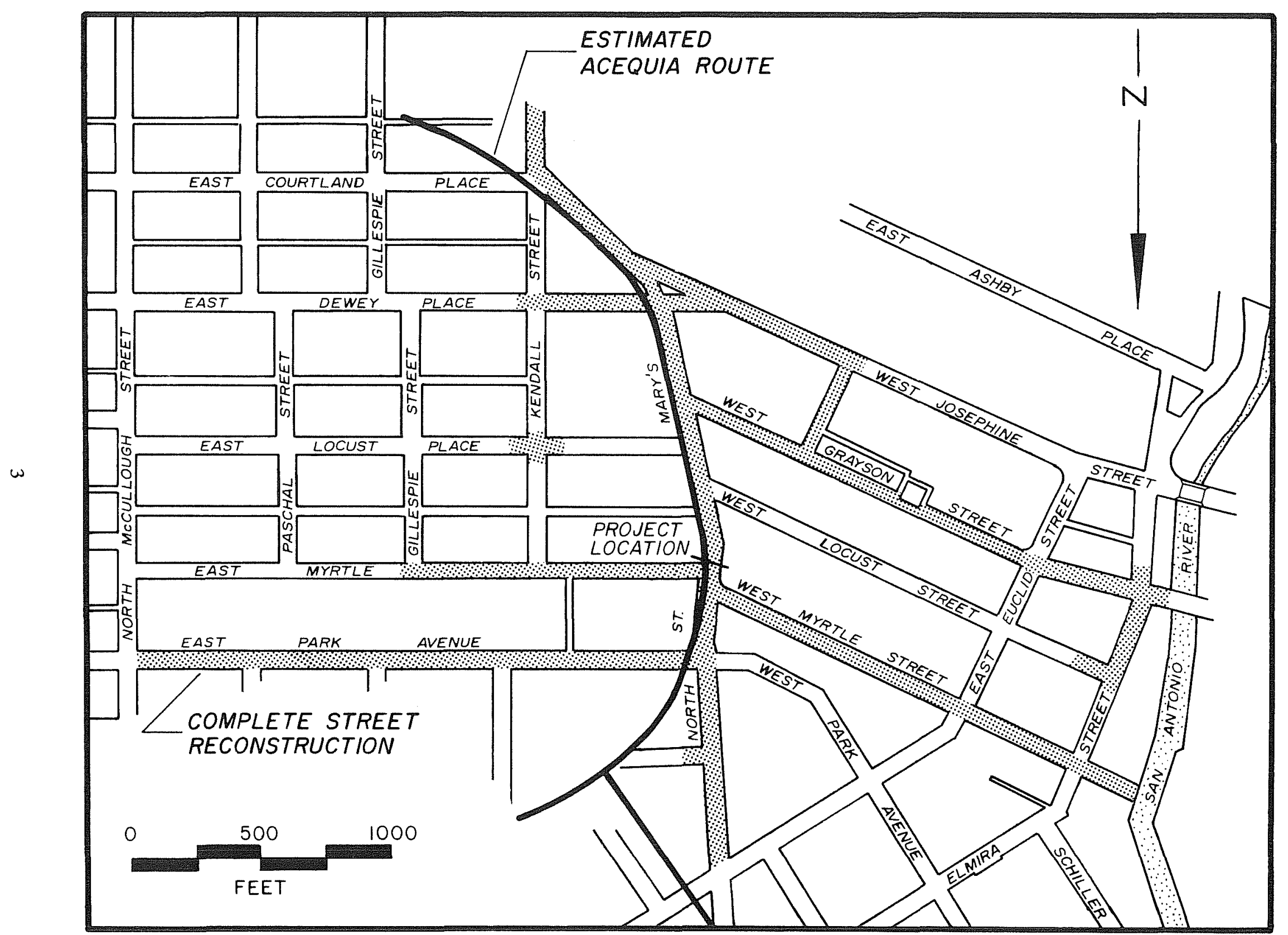

Figure 2. Route of Upper Labor Acequia. 
When the reroute was accomplished excavation began again on the west side of St. Mary's Street. Several feet west of the manhole, on the western edge of the street, an 18-inch cast iron pipe was encountered that appeared to have been set in a broad sloping ditch and covered with a sandy fill. The ditch dropped to a depth of approximately five feet and had a width of about 20 feet (Fig. 3). It appears that an earlier utility crew followed the common practice of using the abandoned acequias for ready-made pipe trenches.

Trench excavations were later observed at East Dewey Place, Grayson Street, and East Park Place, but no other indications of the acequia were found.

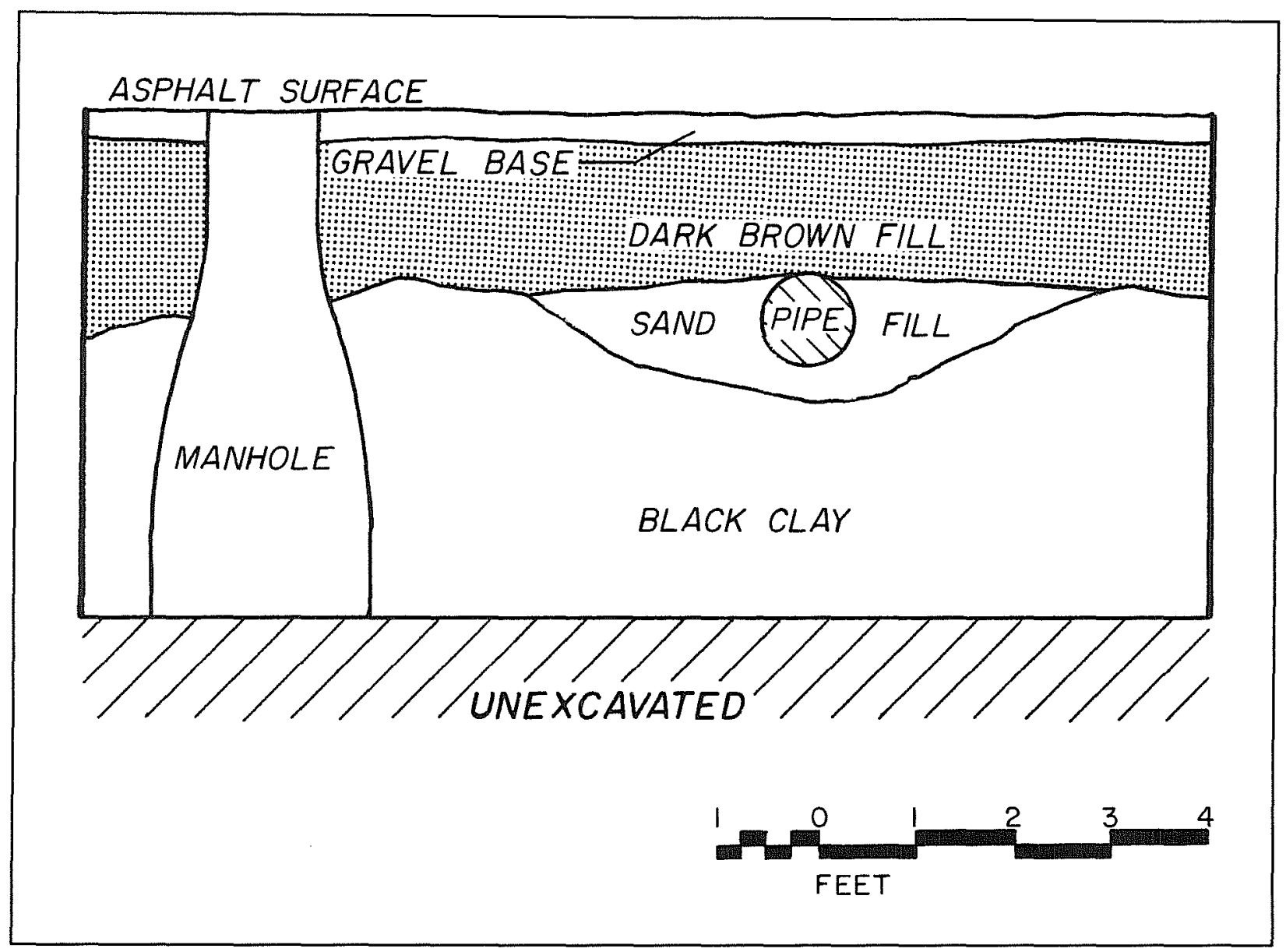

Figure 3. Cross Section of Acequia.

\section{CONCLUSIONS AND RECOMMENDATIONS}

The Upper Labor Acequia played a long and vital role in the history of San Antonio. It is probable that the remainder of the acequia is intact throughout the study area, including a number of stone-lined irrigation control gates. Should any future construction be considered for the area, further archaeological monitoring should be required. We believe that the Upper Labor Acequia meets all basic criteria needed to be eligible for nomination to the National Register of Historic Places. Using the same criteria, we also recommend that the Upper Labor Acequia be designated a State Archeological Landmark. 
Sorrow, W. M.

1972 Archeological Salvage Excavations at the Alamo (Mission San Antonio de Valero) 1970. Texas Archeological Salvage Project, The University of Texas at Austin, Research Report 4.

Taylor, T. U.

1902 Irrigation Systems of Texas. Department of the Interior, United States Government Printing Office, Washington, D. C. 